\title{
Comparison of Model Results Transporting the Odd Nitrogen Family With Results Transporting Separate Odd Nitrogen Species
}

\author{
AnNe R. Douglass ${ }^{1}$
}

Applied Research Corporation, Landover, Maryland

\author{
Charles H. Jackman and Richard S. Stolarski
}

\begin{abstract}
Atmospheric Chemistry and Dynamics Branch, NASA Goddard Space Flight Center, Greenbelt, Maryland
\end{abstract}
\begin{abstract}
We have developed a fast two-dimensional residual circulation stratospheric model. In order to calculate possible effects of long-term changes for trace gases for a large number of scenarios and to examine the model sensitivities to dynamical and photochemical assumptions and inputs, the model is designed to minimize computer requirements. The species continuity equations are solved using process splitting, that is, by successively applying the operators associated with advective changes with photochemical and diffusive forcing. The first study undertaken with this model concerns family chemistry approximations, in which groups of species are related by photochemical equilibrium assumptions and transported as one species. These assumptions are tested by comparing results for the family transport model (FTM), in which odd nitrogen $\left(\mathrm{NO}_{v}=\mathrm{N}+\mathrm{NO}+\mathrm{NO}_{2}+\mathrm{NO}_{3}+2 \mathrm{~N}_{2} \mathrm{O}_{5}\right.$ $+\mathrm{HO}_{2} \mathrm{NO}_{2}+\mathrm{ClONO}_{2}+\mathrm{HNO}_{3}$ ) is transported as a family, with the results for a separate transport model (STM) in which $\mathrm{HNO}_{3}, \mathrm{HO}_{2} \mathrm{NO}_{2}, \mathrm{ClONO}_{2}$ and $\mathrm{N}_{2} \mathrm{O}_{5}$ are transported separately from $\mathrm{NO}_{x}=\mathrm{N}$ $+\mathrm{NO}+\mathrm{NO}_{2}+\mathrm{NO}_{3}$. Two cases are considered: (1) a current atmosphere annual cycle; and (2) a typical scenario for increased fluorocarbons, methane, and nitrous oxide. Although there are differences in odd nitrogen species partitioning, especially at high latitudes, the calculated $\mathrm{O}_{3}$ distributions are nearly identical. For the perturbation scenario the annual average column ozone change and its temporal and spatial characteristics are nearly the same for the FTM and the STM.
\end{abstract}

\section{INTRODUCTION}

It has long been recognized that photochemical equilibrium relationships control the concentrations of some of the trace species that are important in stratospheric photochemistry [e.g., Nicolet, 1965; Crutzen, 1971]. Such species are identified as a family because the reactions by which family members are interchanged are rapid compared to the reactions that result in a net change in family concentration. In a model the family is transported and acted on by the net photochemical source, and the individual species are calculated from the equilibrium relationships. There are significant practical gains to be had from these assumptions, including reduction in the number of species for which the continuity equations must be solved, an increase in the photochemical time scale, and elimination of a diurnal cycle for the transported family, even if the individual members exhibit diurnal variations. Results from family approximation calculations have been found to agree with results from separate species calculations in one-dimensional middlelatitude models [e.g., Solomon, 1981; Cicerone et al., 1983]. Furthermore, the diffusion term used to represent transport by nonzonal processes may be a better description of family transport than individual member transport. The constituent flux is related to the horizontal and vertical constituent gradients and to diffusion coefficients, which are derived for conservative tracers. Pyle and Rogers [1980] considered the problem of calculating transport for reactive species using

\footnotetext{
'Now at University Space Research Association, Columbia, Maryland.

Copyright 1989 by the American Geophysical Union.

Paper number 89JD00668.

0148-0227/89/89JD-00668\$05.00
}

the same diffusion coefficients for each species, and they showed that the errors in the calculated flux for reactive species were larger than for longer-lived families.

Although these approximations are used in many twodimensional models [World Meteorological Organization $(W M O), 1981]$, the photochemical lifetime in the lower stratosphere during high-latitude winter becomes long for species such as $\mathrm{HNO}_{3}$. In these situations family approximations fail, and although the total family concentration may be calculated correctly, the partitioning among the species may be in error.

In order to perform sensitivity studies to dynamical and photochemical inputs and assumptions that are required in developing two-dimensional models, we have developed a fast two-dimensional residual circulation stratospheric model. In this model the species continuity equations are solved using process splitting to combine advective changes with photochemical and diffusive forcing. Using a 1-day time step, 1 year of model integration is completed in less than 30 min, using a Floating Point Systems 164, which is attached to a VAX 11/780. This model has been used in sensitivity studies. In a companion paper [Jackman et al., this issue] we consider the sensitivity of calculated total ozone to dynamical inputs. In this paper we examine the use of family approximations for the odd nitrogen family. Calculations of species concentrations for the present atmosphere and for the atmosphere resulting from a standard perturbation scenario are compared for the baseline family transport model (FTM) and for a separate transport model (STM). In the FTM, $\mathrm{NO}_{y}=\mathrm{N}+\mathrm{NO}+\mathrm{NO}_{2}+\mathrm{NO}_{3}+\mathrm{HNO}_{3}+\mathrm{ClONO}_{2}$ $+2 \mathrm{~N}_{2} \mathrm{O}_{5}+\mathrm{HO}_{2} \mathrm{NO}_{2}$ is transported as a family, and in the STM, $\mathrm{NO}_{x}=\mathrm{N}+\mathrm{NO}+\mathrm{NO}_{2}+\mathrm{NO}_{3}$ is transported as a family, and $\mathrm{HNO}_{3}, \mathrm{~N}_{2} \mathrm{O}_{5}, \mathrm{ClONO}_{2}$ and $\mathrm{HO}_{2} \mathrm{NO}_{2}$ are trans- 
TABLE 1. Lower Boundary Conditions for All Transported Species

\begin{tabular}{|c|c|c|}
\hline Species & Type of Boundary Condition & Value \\
\hline $\mathrm{N}_{2} \mathrm{O}$ & mixing ratio & 300 ppbv \\
\hline $\mathrm{CH}_{4}$ & mixing ratio & $1.6 \mathrm{ppmv}$ \\
\hline $\mathrm{CO}$ & mixing ratio & 100 ppbv \\
\hline $\mathrm{H}_{2}$ & mixing ratio & 500 ppbv \\
\hline $\mathrm{CH}_{3} \mathrm{OOH}$ & fux & $0.0 \mathrm{~cm}^{-2} \mathrm{~s}^{-1}$ \\
\hline $\mathrm{CH}_{3} \mathrm{Cl}$ & mixing ratio & 700 pptv \\
\hline $\mathrm{CH}_{3} \mathrm{CCl}_{3}$ & mixıng ratıo & 100 pptv \\
\hline $\mathrm{CCl}_{4}$ & mixing ratio & $100 \mathrm{pptv}$ \\
\hline $\mathrm{CFCl}_{3}$ & mixıng ratio & 170 pptv \\
\hline $\mathrm{CF}_{2} \mathrm{Cl}_{2}$ & mixing ratio & 285 ppiv \\
\hline $\mathrm{O}_{\mathrm{r}}$ & deposition velocity & $0.1 \mathrm{~cm} \mathrm{~s}^{-1}$ \\
\hline $\mathrm{NO}_{y}$ & mixıng ratio & 100 pptv \\
\hline $\mathrm{Cl}_{y}$ & flux & $0.0 \mathrm{~cm}^{-2} \mathrm{~s}^{-1}$ \\
\hline
\end{tabular}

ported separately. Good agreement between calculated species concentrations and the ozone response indicates the general applicability of the family approximations.

\section{Model Description}

The two-dimensional residual circulation stratospheric model used for these comparisons covers the latitude range from $85^{\circ} \mathrm{S}$ to $85^{\circ} \mathrm{N}$ in $10^{\circ}$ bands. The altitude ranges from the surface to about $60 \mathrm{~km}(0.23 \mathrm{mbar})$. The 30 vertical levels are equally spaced in log pressure, corresponding to a separation of about $2 \mathrm{~km}$. Major species $\mathrm{N}_{2}$ (78\% of the atmosphere) and $\mathrm{O}_{2}(21 \%$ of the atmosphere) are calculated by solving the hydrostatic equation, using monthly average temperature fields from the National Meteorological Center (NMC) for 1000-0.4 mbar and CIRA (1978) above 0.4 mbar [Rosenfield et al., 1987]. The stratospheric $\mathrm{H}_{2} \mathrm{O}$ distribution is fixed and taken from limb infrared monitor of the stratosphere (LIMS) measurements. Previous two-dimensional (2D) model computations, which were shown to agree with specific humidity data [Newell et al., 1972] are used for tropospheric values [Jackman et al., 1987]. This model calculates 34 other minor species. The family approach is used to transport three groups of species: $\mathrm{O}_{\mathrm{r}}\left(\mathrm{O}_{3}, \mathrm{O}\left({ }^{1} D\right), \mathrm{O}\left({ }^{3} P\right)\right), \mathrm{NO}_{v}\left(\mathrm{~N}, \mathrm{NO}, \mathrm{NO}_{2}\right.$, $\mathrm{NO}_{3}, \mathrm{HNO}_{3}, \mathrm{HO}_{2} \mathrm{NO}_{2}, \mathrm{~N}_{2} \mathrm{O}_{5}, \mathrm{ClONO}_{2}$ ), and $\mathrm{Cl},(\mathrm{Cl}, \mathrm{ClO}$, $\mathrm{HCl}, \mathrm{HOCl}, \mathrm{ClONO}{ }_{2}$ ). Other transported species include source gases $\left(\mathrm{N}_{2} \mathrm{O}, \mathrm{CH}_{4}, \mathrm{H}_{2}, \mathrm{CFCl}_{3}, \mathrm{CF}_{2} \mathrm{Cl}_{2}, \mathrm{CH}_{3} \mathrm{Cl}, \mathrm{CCl}_{4}\right.$, $\mathrm{CH}_{3} \mathrm{CCl}_{3}$ ) and minor species, which are produced photochemically but are subject to transport effects (CO, $\left.\mathrm{CH}_{3} \mathrm{OOH}\right)$. The odd hydrogen species $\left(\mathrm{H}, \mathrm{OH}, \mathrm{HO}_{2}, \mathrm{H}_{2} \mathrm{O}_{2}\right)$ and hydrocarbons $\left(\mathrm{CH}_{3}, \mathrm{CH}_{3} \mathrm{O}, \mathrm{CH}_{3} \mathrm{O}_{2}, \mathrm{CH}_{2} \mathrm{O}, \mathrm{CHO}\right)$ are calculated using photochemical equilibrium assumptions. Lower boundary conditions for the transported species are given in Table 1. The upper boundary for all transported species is zero flux. We have included odd nitrogen sources from galactic cosmic rays [Jackman et al., 1987], and the $\mathrm{H} 2$ lightning source of Ko et al. [1986].

\section{Photolysis and Chemical Reaction Rate Constant Data}

Reaction rate constants are updated monthly when the temperature changes. Binary rate constants, given in Table 2 , and tertiary rate constants, given in Table 3, are taken from DeMore et al. [1987]. Daytime average values of photolysis reaction rates (Table 4) are calculated at 10-day intervals, using the two-stream radiative transfer method of Herman [1979], which is based on the matrix operator method of Plass et al. [1973]. Effects of spherical geometry are approximated by use of the Chapman function [McCartney, 1976]. Cross sections are taken from DeMore et al. [1987]; the calculations of the photolysis rates for the Schumann-Runge bands of $\mathrm{O}_{2}$ and the gamma bands of $\mathrm{NO}$ follow Allen and Frederick [1982]. The 39 wavelength intervals, including the 17 spectral regions of the $\mathrm{O}_{2}$ Schumann-Runge bands, are given with solar flux values $[W M O, 1986]$ in Table 5 .

\section{Circulation and Diffusion}

The circulation is calculated from the heating rates, following Dunkerton [1978], and like the temperature field is updated monthly. Sensitivity of model results to the circulation is discussed by Jackman et al. [this issue]. Between 1000 and 100 mbar, the heating rates, including latent heat, are taken from Dopplick [1974, 1979]. From 100-0.23 mbar (the top of the model), the heating rates are taken from Rosenfield et al. [1987]. The zonally averaged meridional wind $\bar{v}$ is calculated from the zonally averaged vertical wind field $\bar{w}$, so that a constant tracer field is unchanged when acted on by the nondispersive transport scheme outlined by Prather [1986]. The seasonal and latitudinal variability of the total ozone distribution produced with this circulation compares well with solar backscattered ultraviolet (SBUV) and Total Ozone Mapping Spectrometer (TOMS) measurements of total ozone [Jackman et al., this issue]. The changes with time in the calculated ozone distribution are relatively smooth, indicating that monthly updating of the circulation and temperature distribution is sufficient.

The diffusion terms, e.g.,

$$
\frac{1}{R \cos \theta} \frac{\partial}{\partial \theta}\left[m K_{y} \frac{1}{R \cos \theta} \frac{\partial \chi}{\partial \theta}\right]
$$

where $\chi$ is the mixing ratio, $\theta$ is the latitude, $R$ is the radius of the Earth, $m$ is the number density, and $K_{v y}$ is the diffusion, are evaluated at each grid point $i$, using centered differences. The term in brackets is evaluated at half points $i+1 / 2$ and $i-1 / 2$ by interpolating $m$ and $K_{y v}$ and by using centered differences for $\partial \chi / \partial \theta$, i.e..

$$
\left.\frac{\partial \chi}{\partial \theta}\right|_{1+1 / 2}=\frac{\chi_{1}+1-\chi_{1}}{\Delta \theta}
$$

Evaluating the derivatives is straightforward, and assuming that there is zero diffusive flux at the boundaries, the integral of the diffusion terms is zero. The $K_{v v}$ values are calculated from a computation of the potential vorticity, using the same temperature data set as the circulation [Newman et al., 1988; Jackman et al., 1988]. The $K_{y z}$ values are related to these $K_{v v}$ values through the potential temperature gradients [Newman et al., 1986, 1988]. The $K_{y z}$ distribution simply relates the mixing on isentropic surfaces to the mixing on pressure surfaces. We use fixed $K_{z z}$ of $2 \times 10^{3} \mathrm{~cm}^{2} \mathrm{~s}^{-1}$ in the stratosphere. This is approximately the value suggested by Ko et al. [1985], but it is substantially smaller than the values used by Solomon et al. [1985], which range from $1 \times 10^{3} \mathrm{~cm}^{2}$ $\mathrm{s}^{-1}$ at $20 \mathrm{~km}$ to $2 \times 10^{5} \mathrm{~cm}^{2} \mathrm{~s}^{-1}$ at $60 \mathrm{~km}$. Model sensitivity to $K_{z:}$ is considered by Jackman et al. [this issue]. In the troposphere, $K_{z z}$ increases with decreasing altitude from the stratospheric value at the tropopause to $1 \times 10^{5} \mathrm{~cm}^{2} \mathrm{~s}^{-1}$ at the ground. 
TABLE 2. Binary Reactions and Rate Constants

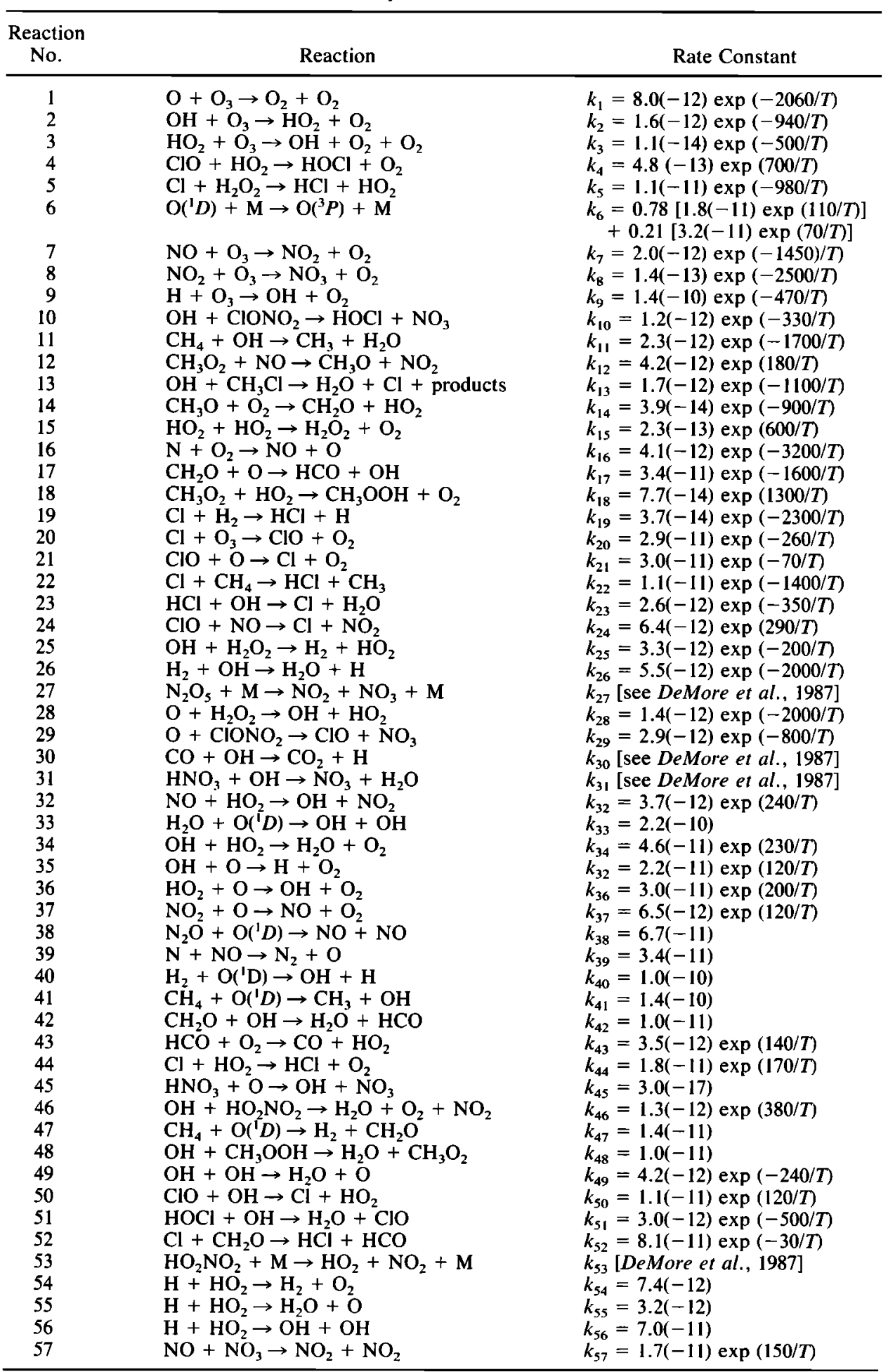

Binary reactions (in units of $\mathrm{cm}^{3} \mathrm{~s}^{-1}$ ) are from Table 1 of DeMore et al. [1987]. In the rate constants, read $8.0(-12)$ as $8.0 \times 10^{-12}$.

\section{Diurnal Variations}

The families and species which are transported in this model do not exhibit diurnal variations, but the diurnal behavior of individual species must be taken into account to calculate photochemical production and loss for families and species. Species which disappear rapidly after sunset for this altitude range, including $\mathrm{O}\left({ }^{3} P\right), \mathrm{O}\left({ }^{1} D\right), \mathrm{N}, \mathrm{NO}, \mathrm{Cl}, \mathrm{H}, \mathrm{OH}$, and $\mathrm{HO}_{2}$, are assumed to be zero at night. The daytime average values of $\mathrm{NO}_{2}$ and $\mathrm{ClO}$ are required to calculate the odd oxygen loss due to reactions $\mathrm{NO}_{2}+\mathrm{O}$ and $\mathrm{ClO}+\mathrm{O}$. The daytime values of these species depend upon the daytime values of reservoir species $\mathrm{N}_{2} \mathrm{O}_{5}$ and $\mathrm{ClONO}_{2}$. Both of these species exhibit large diurnal variations, building up at night and decreasing during the day. The nighttime produc- 
TABLE 3. Tertiary Reactions and Rate Constants

\begin{tabular}{|c|c|c|c|c|c|}
\hline \multirow{2}{*}{$\begin{array}{c}\text { Reaction } \\
\text { No. }\end{array}$} & \multirow[b]{2}{*}{ Reaction } & \multicolumn{2}{|c|}{ Low Pressure Limit* } & \multicolumn{2}{|c|}{ High Pressure Limit $\dagger$} \\
\hline & & $k_{0}^{300}, \mathrm{~cm}^{6} \mathrm{~s}^{-1}$ & $n$ & $k_{\infty}^{300}, \mathrm{~cm}^{3} \mathrm{~s}^{-1}$ & $m$ \\
\hline 58 & $\mathrm{O}+\mathrm{O}_{2}+\mathrm{M} \rightarrow \mathrm{O}_{3}+\mathrm{M}$ & $6.0(-34)$ & 2.3 & $\ldots$ & ... \\
\hline 59 & $\mathrm{H}+\mathrm{O}_{2}+\mathrm{M} \rightarrow \mathrm{HO}_{2}+\mathrm{M}$ & $5.7(-32)$ & 1.6 & $7.5(-11)$ & 0 \\
\hline 60 & $\mathrm{OH}+\mathrm{OH}+\mathrm{M} \rightarrow \mathrm{H}_{2} \mathrm{O}_{2}+\mathrm{M}$ & $6.9(-31)$ & 0.8 & $1.0(-11)$ & 1 \\
\hline 61 & $\mathrm{OH}+\mathrm{NO}_{2}+\mathrm{M} \rightarrow \mathrm{HNO}_{3}+\mathrm{M}$ & $2.6(-30)$ & 3.2 & $2.4(-11)$ & 1.3 \\
\hline 62 & $\mathrm{ClO}+\mathrm{NO}_{2}+\mathrm{M} \rightarrow \mathrm{ClONO}_{2}+\mathrm{M}$ & $1.8(-31)$ & 3.4 & $1.5(-11)$ & 1.9 \\
\hline 63 & $\mathrm{HO}_{2}+\mathrm{NO}_{2}+\mathrm{M} \rightarrow \mathrm{HO}_{2} \mathrm{NO}_{2}+\mathrm{M}$ & $1.8(-31)$ & 3.2 & $4.7(-12)$ & 1.4 \\
\hline 64 & $\mathrm{NO}_{2}+\mathrm{O}+\mathrm{M} \rightarrow \mathrm{NO}_{3}+\mathrm{M}$ & $9.0(-32)$ & 2.0 & $2.2(-11)$ & 0 \\
\hline 65 & $\mathrm{NO}_{2}+\mathrm{NO}_{3}+\mathrm{M} \rightarrow \mathrm{N}_{2} \mathrm{O}_{5}+\mathrm{M}$ & $2.2(-30)$ & 4.3 & $1.5(-12)$ & 0.5 \\
\hline 66 & $\mathrm{CH}_{3}+\mathrm{O}_{2}+\mathrm{M} \rightarrow \mathrm{CH}_{3} \mathrm{O}_{2}+\mathrm{M}$ & $4.5(-31)$ & 2.0 & $1.8(-12)$ & 1.7 \\
\hline 67 & $\mathrm{HO}_{2}+\mathrm{HO}_{2}+\mathrm{M} \rightarrow \mathrm{H}_{2} \mathrm{O}_{2}+\mathrm{O}_{2}+\mathrm{M}$ & $k_{67} \ddagger$ & & & \\
\hline 68 & $\mathrm{OH}+\mathrm{HO}_{2}+\mathrm{M} \rightarrow \mathrm{H}_{2} \mathrm{O}+\mathrm{O}_{2}+\mathrm{M}$ & $k_{68} \ddagger$ & & & \\
\hline
\end{tabular}

Tertiary reactions are from Table 2 of DeMore et al. [1987]. Tertiary rate constants are given by $k=\left[k_{0}(T)\right] /\left[1+k_{0}(T)[\mathrm{M}] / k_{\infty}(T)\right]$ $0.6^{\left\{1+\left[\log _{10}\left(h_{0}(T)[\mathrm{M}] / h \times(T)\right]^{2}\right\}^{-1}\right.}$. Read 6.0(-34) as $6.0 \times 10^{-34}$.

${ }^{*}$ Low pressure limit is $k_{0}=k_{0}^{300}(T / 300)^{-n}$.

†High pressure limit is $k_{\infty}(T)=k_{\infty}^{300}(T / 300)^{-m}$.

†See DeMore et al. [1987].

tion of $\mathrm{ClONO}_{2}$ and $\mathrm{N}_{2} \mathrm{O}_{5}$ at the expense of $\mathrm{NO}_{2}$ is calculated at each grid point for each time step. The calculation is simplified by assuming for each grid point and time step that the difference $\left[\mathrm{NO}_{y}\right]-\left[\mathrm{HNO}_{3}\right]-\left[\mathrm{HO}_{2} \mathrm{NO}_{2}\right] \equiv \gamma$ is fixed. Similarly, $\left[\mathrm{Cl}_{y}\right]-[\mathrm{HCl}]-[\mathrm{HOCl}] \equiv \beta$ is assumed fixed. The sunset values of $\mathrm{N}_{2} \mathrm{O}_{5}$ and $\mathrm{ClONO}_{2}$ are calculated from their current daytime average values, accounting for daytime production and loss processes. The sunset value of $\mathrm{NO}_{2}$, a necessary boundary condition for the nighttime calculation, is the difference $\gamma-2\left[\mathrm{~N}_{2} \mathrm{O}_{5}\right]^{\text {sunset }}-\left[\mathrm{ClONO}_{2}\right]^{\text {sunset }}$; the sunset value of $\mathrm{ClO}$ is the difference $\beta-\left[\mathrm{ClONO}_{2}\right]^{\text {sunset }}$. The nighttime increases in $\mathrm{N}_{2} \mathrm{O}_{5}$ and $\mathrm{ClONO}_{2}$ are calculated by integrating

TABLE 4. Photodissociations

\begin{tabular}{|c|c|c|}
\hline $\begin{array}{c}\text { Reaction } \\
\text { No. }\end{array}$ & Reaction & $\begin{array}{c}\text { Maximum } \\
\text { Wavelength } \\
\text { for Photolysis }\end{array}$ \\
\hline 69 & $\mathrm{O}_{2} \rightarrow \mathrm{O}+\mathrm{O}$ & $J_{60}<242 \mathrm{~nm}$ \\
\hline 70 & $\mathrm{O}_{3} \rightarrow \mathrm{O}_{2}+\mathrm{O}\left({ }^{\prime} D\right)$ & $J_{70}<310 \mathrm{~nm}$ \\
\hline 71 & $\mathrm{O}_{3} \rightarrow \mathrm{O}_{2}+\mathrm{O}\left({ }^{3} P\right)$ & $J_{71}<1140 \mathrm{~nm}$ \\
\hline 72 & $\mathrm{NO} \rightarrow \mathrm{N}+\mathrm{O}$ & $J_{72}<191 \mathrm{~nm}$ \\
\hline 73 & $\mathrm{NO}_{2} \rightarrow \mathrm{NO}+\mathrm{O}$ & $J_{73}<400 \mathrm{~nm}$ \\
\hline 74 & $\mathrm{NO}_{3} \rightarrow \mathrm{NO}_{2}+\mathrm{O}$ & $J_{74}<700 \mathrm{~nm}$ \\
\hline 75 & $\mathrm{NO}_{3} \rightarrow \mathrm{NO}+\mathrm{O}_{2}$ & $J_{75}<700 \mathrm{~nm}$ \\
\hline 76 & $\mathrm{~N}_{2} \mathrm{O}_{5} \rightarrow \mathrm{NO}_{2}+\mathrm{NO}_{3}$ & $J_{76}<380 \mathrm{~nm}$ \\
\hline 77 & $\mathrm{~N}_{2} \mathrm{O} \rightarrow \mathrm{N}_{2}+\mathrm{O}\left({ }^{\prime} D\right)$ & $J_{77}<240 \mathrm{~nm}$ \\
\hline 78 & $\mathrm{HNO}_{3} \rightarrow \mathrm{OH}+\mathrm{NO}_{2}$ & $J_{78}<546 \mathrm{~nm}$ \\
\hline 79 & $\mathrm{HO}_{2} \mathrm{NO}_{2} \rightarrow \mathrm{OH}+\mathrm{NO}_{3}$ & $J_{79}<330 \mathrm{~nm}$ \\
\hline 80 & $\mathrm{ClONO}_{2} \rightarrow \mathrm{Cl}+\mathrm{NO}_{3}$ & $J_{80}<450 \mathrm{~nm}$ \\
\hline 81 & $\mathrm{H}_{2} \mathrm{O} \rightarrow \mathrm{H}+\mathrm{OH}$ & $J_{81}<191 \mathrm{~nm}$ \\
\hline 82 & $\mathrm{H}_{2} \mathrm{O}_{2} \rightarrow \mathrm{OH}+\mathrm{OH}$ & $J_{82}<265 \mathrm{~nm}$ \\
\hline 83 & $\mathrm{CH}_{2} \mathrm{O} \rightarrow \mathrm{HCO}+\mathrm{H}$ & $J_{83}<330 \mathrm{~nm}$ \\
\hline 84 & $\mathrm{CH}_{2} \mathrm{O} \rightarrow \mathrm{H}_{2}+\mathrm{CO}$ & $J_{84}<360 \mathrm{~nm}$ \\
\hline 85 & $\mathrm{CH}_{3} \mathrm{OOH} \rightarrow \mathrm{CH}_{3} \mathrm{O}+\mathrm{OH}$ & $J_{85}<350 \mathrm{~nm}$ \\
\hline 86 & $\mathrm{HCl} \rightarrow \mathrm{H}+\mathrm{Cl}$ & $J_{86}<220 \mathrm{~nm}$ \\
\hline 87 & $\mathrm{HOCl} \rightarrow \mathrm{OH}+\mathrm{Cl}$ & $J_{87}<420 \mathrm{~nm}$ \\
\hline 88 & $\mathrm{CCl}_{4} \rightarrow 4(\mathrm{Cl})+$ products & $J_{88}<216 \mathrm{~nm}$ \\
\hline 89 & $\mathrm{CH}_{3} \mathrm{Cl} \rightarrow(\mathrm{Cl})+$ products & $J_{89}<216 \mathrm{~nm}$ \\
\hline 90 & $\mathrm{CFCl}_{3} \rightarrow 3(\mathrm{Cl})+$ products & $J_{90}<260 \mathrm{~nm}$ \\
\hline 91 & $\mathrm{CF}_{2} \mathrm{Cl}_{2} \rightarrow 2(\mathrm{Cl})+$ products & $J_{91}<240 \mathrm{~nm}$ \\
\hline 92 & $\mathrm{CH}_{3} \mathrm{CCl}_{3} \rightarrow 3(\mathrm{Cl})+$ products & $J_{92}<240 \mathrm{~nm}$ \\
\hline
\end{tabular}

The cross sections are taken from DeMore et al. [1987]. Schumann-Runge bands of $\mathrm{O}_{2}$ and the gamma bands of $\mathrm{NO}$ are taken from Allen and Frederick [1982].

$$
\begin{gathered}
\frac{\partial\left[\mathrm{N}_{2} \mathrm{O}_{5}\right]}{\partial t}=k_{\mathrm{NO}_{3}, \mathrm{NO}_{2}, \mathrm{M}}\left[\mathrm{NO}_{3}\right]\left[\mathrm{NO}_{2}\right][\mathrm{M}]-k_{\mathrm{N}_{2} \mathrm{O}_{5}, \mathrm{M}}\left[\mathrm{N}_{2} \mathrm{O}_{5}\right][\mathrm{M}] \\
\frac{\partial\left[\mathrm{ClONO}_{2}\right]}{\partial t}=k_{\mathrm{ClO}, \mathrm{NO}_{2}, \mathrm{M}}[\mathrm{ClO}]\left[\mathrm{NO}_{2}\right][\mathrm{M}]
\end{gathered}
$$

noting that both $\left[\mathrm{NO}_{2}\right]$ and $[\mathrm{ClO}]$ are functions of time. Further, it is assumed that nighttime $\mathrm{NO}_{3}$ is in steady state and can be replaced in (1) by solving

$$
\begin{aligned}
\frac{\partial\left[\mathrm{NO}_{3}\right]}{\partial t}=k_{\mathrm{N}_{2} \mathrm{O}_{5}, \mathrm{M}}\left[\mathrm{N}_{2} \mathrm{O}_{5}\right][\mathrm{M}]+k_{\mathrm{NO}_{2}, \mathrm{O}_{3}}\left[\mathrm{NO}_{2}\right]\left[\mathrm{O}_{3}\right] \\
-k_{\mathrm{NO}_{1}, \mathrm{NO}_{2}, \mathrm{M}}\left[\mathrm{NO}_{3}\right]\left[\mathrm{NO}_{2}\right][\mathrm{M}]=0
\end{aligned}
$$

for $\left[\mathrm{NO}_{3}\right]$. These new dawn values for $\left[\mathrm{ClONO} \mathrm{O}_{2}\right]$ and $\left[\mathrm{N}_{2} \mathrm{O}_{5}\right]$ are used with daytime production and loss processes to calculate the ratios $\left[\mathrm{ClONO}_{2}\right]^{\text {day }} /\left[\mathrm{NO}_{2}\right]^{\text {day }}$ and $\left[\mathrm{N}_{2} \mathrm{O}_{5}\right]^{\text {day }} /$ $\left[\mathrm{NO}_{2}\right]^{\text {day }}$, which are needed in the partitioning of total odd nitrogen, as described in the following section on family approximations.

\section{Family Approximations}

There are three chemical families that are transported in the basic model: $\mathrm{O}_{x}=\mathrm{O}+\mathrm{O}_{3}+\mathrm{O}\left({ }^{1} D\right) ; \mathrm{NO}_{y}=\mathrm{N}+\mathrm{NO}+$ $\mathrm{NO}_{2}+\mathrm{NO}_{3}+2 \mathrm{~N}_{2} \mathrm{O}_{5}+\mathrm{HNO}_{3}+\mathrm{HO}_{2} \mathrm{NO}_{2}+\mathrm{ClONO}_{2}$; and $\mathrm{Cl}_{y}=\mathrm{Cl}+\mathrm{ClO}+\mathrm{HCl}+\mathrm{HOCl}+\mathrm{ClONO}_{2}$. We assume that family member species are in photochemical equilibrium with each other because the reactions that produce interchanges among members of a family are rapid compared with the photochemical, transport, and diffusive processes that produce a net change in the family concentration. The general strategy for using family chemistry in this model is outlined using the $\mathrm{NO}_{y}$ family as an example. The net photochemical production for $\mathrm{NO}_{y}$ is the reaction of $\mathrm{N}_{2} \mathrm{O}$ with $O\left({ }^{1} D\right)$. The only stratospheric loss of $\mathrm{NO}_{y}$ is the reaction $\mathrm{N}+\mathrm{NO}$. This must be written as a function of $\mathrm{NO}_{y}$, using the daytime ratios $\mathrm{N} / \mathrm{NO}, \mathrm{NO} / \mathrm{NO}_{2}$, and $\mathrm{NO}_{2} / \mathrm{NO}_{y}$ :

$$
\text { Loss }=k_{\mathrm{N}, \mathrm{NO}} \frac{[\mathrm{N}]}{[\mathrm{NO}]}\left[\frac{[\mathrm{NO}]}{\left[\mathrm{NO}_{2}\right]}\right]^{2}\left[\frac{\left[\mathrm{NO}_{2}\right]}{\left[\mathrm{NO}_{y}\right]}\right]^{2}\left[\mathrm{NO}_{y}\right]^{2}
$$

The daytime ratios $\mathrm{N} / \mathrm{NO}$ and $\mathrm{NO} / \mathrm{NO}_{2}$ are formulated simply, using the production and loss reactions 
TABLE 5. Wavelength Bands and Corresponding Solar Fluxes

\begin{tabular}{cc}
$\begin{array}{c}\text { Wavelength Band, } \\
\text { nm }\end{array}$ & $\begin{array}{c}\text { Solar Flux, } \\
\mathrm{cm}^{-2} \mathrm{~s}^{-1}\end{array}$ \\
\hline 121.567 & $3.00(11)$ \\
$170.0-172.4$ & $7.00(11)$ \\
$172.4-173.9$ & $1.00(11)$ \\
$173.9-175.4$ & $1.00(11)$ \\
$175.4-177.0$ & $1.74(11)$ \\
$177.0-178.6$ & $2.10(11)$ \\
$178.6-180.2$ & $2.38(11)$ \\
$180.2-181.8$ & $3.04(11)$ \\
$181.8-183.5$ & $3.19(11)$ \\
$183.5-185.2$ & $2.93(11)$ \\
$185.2-186.9$ & $3.62(11)$ \\
$186.9-188.7$ & $4.73(11)$ \\
$188.7-190.5$ & $5.61(11)$ \\
$190.5-192.3$ & $6.63(11)$ \\
$192.3-194.2$ & $6.90(11)$ \\
$194.2-196.1$ & $9.56(11)$ \\
$196.1-198.0$ & $1.15(12)$ \\
$198.0-200.0$ & $1.27(12)$ \\
$200.0-202.0$ & $1.52(12)$ \\
$202.0-210.5$ & $1.12(13)$ \\
$210.5-219.8$ & $3.47(13)$ \\
$219.8-229.9$ & $5.53(13)$ \\
$229.9-241.0$ & $6.00(13)$ \\
$241.0-253.2$ & $8.10(13)$ \\
$253.2-266.7$ & $2.31(14)$ \\
$266.7-281.7$ & $4.16(14)$ \\
$281.7-285.7$ & $1.52(14)$ \\
$285.7-298.5$ & $9.03(14)$ \\
$298.5-303.0$ & $3.22(14)$ \\
$303.0-307.7$ & $4.23(14)$ \\
$307.7-312.5$ & $4.95(14)$ \\
$312.5-317.5$ & $5.44(14)$ \\
$317.5-322.5$ & $5.93(14)$ \\
$322.5-337.5$ & $2.29(15)$ \\
$337.5-357.5$ & $3.42(15)$ \\
$357.5-377.5$ & $3.96(15)$ \\
$377.5-397.5$ & $4.08(15)$ \\
$397.5-547.5$ & $6.72(16)$ \\
$547.5-735.0$ & $9.81(16)$ \\
\hline 3.0 & \\
\hline 00111953.00 & \\
\hline &
\end{tabular}

Read $3.00(11)$ as $3.00 \times 10^{11}$

$$
\begin{aligned}
& \frac{[\mathrm{N}]}{[\mathrm{NO}]}=\frac{J_{\mathrm{NO}}}{k_{\mathrm{N}, \mathrm{NO}}[\mathrm{NO}]+k_{\mathrm{N}, \mathrm{O}_{2}}\left[\mathrm{O}_{2}\right]} \\
& \frac{[\mathrm{NO}]}{\left[\mathrm{NO}_{2}\right]}=\left\{J_{\mathrm{NO}_{2}}+J_{\mathrm{NO}_{3} \rightarrow \mathrm{NO}+\mathrm{O}_{2}}\left[\mathrm{NO}_{3}\right] /\left[\mathrm{NO}_{2}\right]+k_{\mathrm{NO}_{2}, \mathrm{O}}[\mathrm{O}]\right\} \\
& \text { - }\left\{k_{\mathrm{NO}, \mathrm{O}_{3}}\left[\mathrm{O}_{3}\right]+k_{\mathrm{ClO}, \mathrm{NO}}[\mathrm{ClO}]+k_{\mathrm{HO}_{2}, \mathrm{NO}}\left[\mathrm{HO}_{2}\right]\right. \\
& \left.+k_{\mathrm{CH}_{3} \mathrm{O}_{2}, \mathrm{NO}}\left[\mathrm{CH}_{3} \mathrm{O}_{2}\right]+k_{\mathrm{NO}_{2} \mathrm{NO}_{3}}\left[\mathrm{NO}_{3}\right]\right\}^{-1}
\end{aligned}
$$

An expression for the daytime ratio $\mathrm{NO}_{2} / \mathrm{NO}_{v}$ is derived from the definition of $\mathrm{NO}_{y}$; daytime ratios of each species to $\mathrm{NO}_{2}$ are required.

$$
\begin{aligned}
\frac{\left[\mathrm{NO}_{2}\right]}{\left[\mathrm{NO}_{y}\right]}= & \left\{1+\frac{[\mathrm{N}]}{\left[\mathrm{NO}_{2}\right]}+\frac{[\mathrm{NO}]}{\left[\mathrm{NO}_{2}\right]}+\frac{\left[\mathrm{NO}_{3}\right]}{\left[\mathrm{NO}_{2}\right]}+\frac{\left[\mathrm{HNO}_{3}\right]}{\left[\mathrm{NO}_{2}\right]}\right. \\
& \left.+\frac{2\left[\mathrm{~N}_{2} \mathrm{O}_{5}\right]}{\left[\mathrm{NO}_{2}\right]}+\frac{\left[\mathrm{HO}_{2} \mathrm{NO}_{2}\right]}{\left[\mathrm{NO}_{2}\right]}+\frac{\left[\mathrm{ClONO}_{2}\right]}{\left[\mathrm{NO}_{2}\right]}\right\}^{-1}
\end{aligned}
$$

Expressions analogous to the $\mathrm{NO} / \mathrm{NO}_{2}$ ratio are derived for ratios such as $\mathrm{HNO}_{3} / \mathrm{NO}_{2}$ and $\mathrm{HO}_{2} \mathrm{NO}_{2} / \mathrm{NO}_{2}$. The ratios $\mathrm{N}_{2} \mathrm{O}_{5} / \mathrm{NO}_{2}$ and $\mathrm{ClONO}_{2} / \mathrm{NO}_{2}$ are formed accounting for their diurnal cycles, as described previously. After calculating the updated value of $\mathrm{NO}_{y}$ by solving the species continuity equations, the individual species concentrations are calculated using these ratios.

\section{Solution of the Species Continuity Equation}

The central calculation of this and other models is solution of the longitudinally averaged species continuity equation:

$$
\frac{\partial \chi}{\partial t}=-\mathbf{v} \cdot \nabla \chi+S-D(\chi)
$$

Here $\chi$ represents a species concentration, $\mathbf{v}$ is the wind field, and the first term on the right is advection by the circulation. The photochemical source term $S$ is equal to the difference in the photochemical production and loss terms and is dependent on reaction rate constants, photolysis rates, and other species concentrations. The diffusion term $D$ represents small-scale mixing and also includes the effects of planetary waves and gravity waves.

Assuming that the changes in species concentration for one time step are small, the photochemical terms in the species continuity equations can be evaluated using the previous time step's values for all species concentration. This assumption was tested during developmental stages of the model. Results using this approximation were compared with results in which the species solutions are obtained simultaneously using Newton-Raphson iteration with explicit time differencing at each point and alternating direction of integration [Guthrie et al., 1984]. The speed of the model was found to increase substantially, but the model results were unchanged. Further increases in the model speed were obtained by the implementation of process splitting, that is, by assuming that the advective forcing in the continuity equation can be separated from the diffusive and photochemical forcing [McRae et al., 1982]. It is assumed that the photochemical source term $S$ may be written

$$
S=P-L \chi
$$

where $P$ is the production, $L$ is the loss frequency, and $\chi$ is the species concentration. For species in which the loss process is not linear, the photochemical loss is represented by a Taylor series expansion,

$$
\text { Loss }=\operatorname{Loss}\left(\chi^{0}\right)+\left.\left(\chi^{t}-\chi^{0}\right) \frac{\partial \text { Loss }}{\partial \chi}\right|_{\chi=\chi^{0}}
$$

where the superscripts 0 and $t$ refer to the previous and current time steps, respectively. The constant terms are combined with the production and the coefficient of $\chi^{t}$ is treated as $L$ to produce an equation that is analogous to (9). The continuity equation (8) is written in difference form,

$$
\frac{\chi^{t}-\chi^{0}}{\Delta t}=\frac{\chi^{\prime}-\chi^{0}}{\Delta t}+\left(P-L \chi^{\prime}\right)-D\left(\chi^{\prime}\right)
$$

where $\chi^{t}$ is the result, $\chi^{0}$ the initial condition, and $\chi^{\prime}$ is the advected field. In this model the advected constituent field is calculated using an accurate, efficient, and nondispersive scheme, which was developed by Prather [1986]. The final constituent values are calculated by solving (11) for $\chi^{t}$ :

$$
\chi^{t}=\frac{\left(\chi^{\prime}+\left(P-D\left(\chi^{\prime}\right)\right) \Delta t\right)}{(1+L \Delta t)}
$$


The model time step is usually 1 day; however, for some wind fields this time step may exceed the Courant limit (that is, the distance moved is greater than the grid spacing), especially near the tropopause. In this situation the advective time step is reduced to 0.5 or 0.25 day, as necessary. The advective scheme is applied successively to calculate the result of 1 day's advection; this result is then used in (12) with a 1-day photochemical and diffusive time step. An advantage of this solution scheme is that for species near photochemical equilibrium, when $P$ and $L_{\chi}$ in (11) are large compared to the advective and diffusive terms and are nearly equal to each other, the solution given by (12) reduces to $\chi^{\prime}=P / L$, the photochemical equilibrium limit. The Prather [1986] transport scheme, which conserves first- and secondorder moments of a tracer distribution as well as the total tracer mass, does not create negative mixing ratios as long as the Courant condition is satisfied and does not require diffusion to be stable.

\section{Description of Experiment}

To test the validity of the family approximations, $\mathrm{HNO}_{3}$, $\mathrm{HO}_{2} \mathrm{NO}_{2}, \mathrm{~N}_{2} \mathrm{O}_{5}$, and $\mathrm{ClONO}_{2}$ are transported separately from $\mathrm{NO}_{x}=\mathrm{N}+\mathrm{NO}+\mathrm{NO}_{2}+\mathrm{NO}_{3}$. The reactions in which $\mathrm{HNO}_{3}, \mathrm{HO}_{2} \mathrm{NO}_{2}, \mathrm{~N}_{2} \mathrm{O}_{5}$, and $\mathrm{ClONO}_{2}$ are produced and destroyed are treated as loss and production for $\mathrm{NO}_{\mathbf{r}}$. Modifications to the transport equation are required because the diurnal cycles of $\mathrm{N}_{2} \mathrm{O}_{5}, \mathrm{ClONO}_{2}$, and $\mathrm{NO}_{x}$ must now be considered. The advection and diffusion schemes act on the 24-hour average field, and the 24-hour average production and loss are calculated. For $\mathrm{HNO}_{3}$ and $\mathrm{HO}_{2} \mathrm{NO}_{2}$ the reactions that are needed for production and loss frequency are the same reactions that are used to define the ratios $\mathrm{HNO}_{3} /$ $\mathrm{NO}_{2}$ and $\mathrm{HO}_{2} \mathrm{NO}_{2} / \mathrm{NO}_{2}$, e.g.,

$$
\begin{aligned}
& \frac{\left[\mathrm{HNO}_{3}\right]}{\left[\mathrm{NO}_{2}\right]}=\frac{\left.k_{\mathrm{NO}_{2}, \mathrm{OH} . \mathrm{M}}[\mathrm{OH}][\mathrm{M}]\right]}{k_{\mathrm{OH} \mathrm{HNO}_{3}}[\mathrm{OH}]+J_{\mathrm{HNO}_{3}}} \\
& P\left(\mathrm{HNO}_{3}\right)_{\mathrm{NO}_{\mathrm{r}}}=k_{\mathrm{OH} \mathrm{NO}_{2}, \mathrm{M}}[\mathrm{OH}]\left[\mathrm{NO}_{2}\right][\mathrm{M}] \\
& L\left(\mathrm{HNO}_{3}\right)_{\mathrm{NO}_{1}}=J_{\mathrm{HNO}_{3}}+k_{\mathrm{HNO}_{3} . \mathrm{OH}}[\mathrm{OH}]
\end{aligned}
$$

For production $P$ (loss frequency $L$ ) the species in parentheses is the species being produced (lost) by reactions involving the loss (production) of the family or species that is the subscript. For $\mathrm{N}_{2} \mathrm{O}_{5}$ and $\mathrm{ClONO}_{2}$, nighttime production is calculated by integrating (1) and (2). The updated fields $[\mathrm{X}]^{24}$ calculated from (12) are related back to daytime average values $[\mathrm{X}]^{d}$, following Turco and Whitten [1978], by

$$
[\mathrm{X}]^{24}=f[\mathrm{X}]^{d}+(1-f)[\mathrm{X}]^{n}=[\mathrm{X}]^{d}[f+(1-f) A]
$$

where $f$ is the fraction of day and $A$ is the ratio of the nighttime to daytime average concentration. This ratio, considered to be 1 for 24-hour night, is calculated daily from a detailed consideration of the diurnal cycles of $\mathrm{N}_{2} \mathrm{O}_{5}$ and $\mathrm{ClONO}_{2}$, as described previously.

Because the total $\mathrm{NO}_{y}$ should be the same for both calculations, it must be true that the net production and loss of $\mathrm{NO}_{y}$ is unchanged. This, in turn, implies small day-to-day changes in species concentration, illustrated by considering (12) for the four transported species and the family that are part of odd nitrogen

$\left[\mathrm{HNO}_{3}\right]^{t}+L\left(\mathrm{HNO}_{3}\right)_{\mathrm{NO}_{\mathrm{r}}}\left[\mathrm{HNO}_{3}\right]^{t} \Delta t=\left[\mathrm{HNO}_{3}\right]^{\prime}$

$$
+\left[L\left(\mathrm{NO}_{x}\right)_{\mathrm{HNO}_{3}}\left[\mathrm{NO}_{x}\right]^{0}-D\left(\left[\mathrm{HNO}_{3}\right]^{\prime}\right)\right] \Delta t
$$

$\left[\mathrm{HO}_{2} \mathrm{NO}_{2}\right]^{t}+L\left(\mathrm{HO}_{2} \mathrm{NO}_{2}\right)_{\mathrm{NO}_{1}}\left[\mathrm{HO}_{2} \mathrm{NO}_{2}\right]^{t} \Delta t=\left[\mathrm{HO}_{2} \mathrm{NO}_{2}\right]^{\prime}$

$$
+\left[L\left(\mathrm{NO}_{r}\right)_{\mathrm{HO}_{2} \mathrm{NO}_{2}}\left[\mathrm{NO}_{x}\right]^{0}-D\left(\left[\mathrm{HO}_{2} \mathrm{NO}_{2}\right]^{\prime}\right)\right] \Delta t
$$

$$
\begin{aligned}
& {\left[\mathrm{ClONO}_{2}\right]^{t}+L\left(\mathrm{ClONO}_{2}\right)_{\mathrm{NO}_{1}}\left[\mathrm{ClONO}_{2}\right]^{t} \Delta t=\left[\mathrm{ClONO}_{2}\right]} \\
& +\left[L\left(\mathrm{NO}_{x}\right)_{\mathrm{ClONO}_{2}}\left[\mathrm{NO}_{x}\right]^{0}-D\left(\left[\mathrm{ClONO}_{2}\right]^{\prime}\right]\right] \Delta t \\
& 2\left\{\left[\mathrm{~N}_{2} \mathrm{O}_{5}\right]^{t}+L\left(\mathrm{~N}_{2} \mathrm{O}_{5}\right)_{\mathrm{NO}_{4}}\left[\mathrm{~N}_{2} \mathrm{O}_{5}\right]^{t} \Delta t=\left[\mathrm{N}_{2} \mathrm{O}_{5}\right]^{\prime}\right. \\
& \left.+\left[L\left(\mathrm{NO}_{x}\right)_{\mathrm{N}_{2} \mathrm{O}_{5}}-D\left(\left[\mathrm{~N}_{2} \mathrm{O}_{5}\right]^{\prime}\right)\right] \Delta t\right\} \\
& {\left[\mathrm{NO}_{x}\right]^{t}+\left[\sum_{i} L\left(\mathrm{NO}_{x}\right)_{X}+L\left(\mathrm{NO}_{x}\right)\right]\left[\mathrm{NO}_{x}\right]^{t} \Delta t=\left[\mathrm{NO}_{x}\right]} \\
& +\left[\sum_{\imath} L\left(\mathrm{X}_{t}\right)_{\mathrm{NO}_{\mathrm{r}}}\left[\mathrm{X}_{t}\right]^{0}+P\left(\mathrm{NO}_{x}\right)-D\left(\left[\mathrm{NO}_{x}\right]^{\prime}\right)\right] \Delta t
\end{aligned}
$$

For terms $L(\mathrm{X})_{Y}$, the species $\mathrm{X}$ is being lost by reactions that result in the production of $Y$. The unsubscripted terms $L\left(\mathrm{NO}_{x}\right)$ and $P\left(\mathrm{NO}_{x}\right)$ in $(21)$ represent the reactions that result in net changes in $\mathrm{NO}_{y}$ species by producing $\mathrm{NO}_{x}$ from $\mathrm{N}_{2} \mathrm{O}$ and $\mathrm{N}_{2}$ and destroying $\mathrm{NO}_{x}$ by reacting $\mathrm{N}$ with $\mathrm{NO}$. The summation in (21) includes the four species that are now transported separately. Loss of one of the four species in (17)-(20) to produce $\mathrm{NO}$, appears as production of $\mathrm{NO}_{\lambda}$ in (21). The sum of (17)-(21) must be

$$
\begin{aligned}
& {\left[\mathrm{NO}_{y}\right]^{t}+L\left(\mathrm{NO}_{y}\right)\left[\mathrm{NO}_{v}\right]^{t} \Delta t} \\
& =\left[\mathrm{NO}_{y}\right]^{\prime}+\left[P\left(\mathrm{NO}_{v}\right)-D\left(\left[\mathrm{NO}_{y}\right]^{\prime}\right)\right] \Delta t
\end{aligned}
$$

Several approximations must be satisfied for the sum of (17)-(21) to equal (22). Because the transport and diffusion operators are linear, the sums of the transported terms and the diffusion terms from (17) to (21) will equal the corresponding terms in (22) if the separate calculation does not produce differences in the gradients of the species distributions. The sums of the photochemical terms in (17)-(21) will equal the net production and loss in (22) only if there is cancellation among the terms, e.g.,

$L\left(\mathrm{HNO}_{3}\right)_{\mathrm{NO}_{r}}\left[\mathrm{HNO}_{3}\right]^{t} \approx L\left(\mathrm{HNO}_{3}\right)_{\mathrm{NO}_{r}}\left[\mathrm{HNO}_{3}\right]^{0}=P\left(\mathrm{NO}_{\curlyvee}\right)_{\mathrm{HNO}_{3}}$

In situations where photochemical processes control the family member concentrations, there are still differences in the formulation, illustrated by consideration of $\mathrm{HO}_{2} \mathrm{NO}_{2}$. The family approximation requires

$$
\left[\mathrm{HO}_{2} \mathrm{NO}_{2}\right]^{t}=\frac{k_{\mathrm{HO}_{2}, \mathrm{NO}_{2}, \mathrm{M}}\left[\mathrm{HO}_{2}\right][\mathrm{M}]}{J_{\mathrm{HO}_{2} \mathrm{NO}_{2}}+k_{\mathrm{OH}, \mathrm{HO}_{2} \mathrm{NO}_{2}}[\mathrm{OH}]}\left[\mathrm{NO}_{2}\right]^{t}
$$

Neglecting transport, because the photochemical terms are calculated using the previous day's species concentrations, the separate calculation implies

$$
\left[\mathrm{HO}_{2} \mathrm{NO}_{2}\right]^{\prime}=\frac{k_{\mathrm{HO}_{2}, \mathrm{NO}_{2}, \mathrm{M}}\left[\mathrm{HO}_{2}\right][\mathrm{M}]}{J_{\mathrm{HO}_{2} \mathrm{NO}_{2}}+k_{\mathrm{HO}_{2} \mathrm{NO}_{2}, \mathrm{OH}}[\mathrm{OH}]}\left[\mathrm{NO}_{2}\right]^{0}
$$

Agreement between the family and separate calculations therefore implies that for the odd nitrogen species $[\mathrm{X}]^{t} \simeq$ 
$[\mathrm{X}]^{0}$, i.e., that the day-to-day changes in the species concentrations are small. This is important because this assumption is central to our use of the previous day's values to calculate the photochemical terms throughout the model.

\section{RESULTS}

\section{Ambient Atmosphere}

The Family Transport Model (FTM) and the Separate Transport Model (STM) in which $\mathrm{HNO}_{3}, \mathrm{HO}_{2} \mathrm{NO}_{2}, \mathrm{~N}_{2} \mathrm{O}_{5}$, and $\mathrm{ClONO}_{2}$ are transported separately from $\mathrm{NO}_{x}$ were used for 20-year simulations. At equinox the two models produce similar results. To illustrate the validity of the photochemical equilibrium assumption relating $\mathrm{HNO}_{3}$ to $\mathrm{NO}_{y}$, the $\mathrm{HNO}_{3}$ / $\mathrm{NO}_{2}$ from the STM and FTM are compared in Figure 1. In the FTM it is assumed that $\mathrm{HNO}_{3}$ is given by (13) times $\left[\mathrm{NO}_{2}\right]^{t}$, where $\left[\mathrm{NO}_{2}\right]^{t}$ is calculated from $\mathrm{NO}_{y}$ using (7). In the STM the calculation of $\mathrm{HNO}_{3}$ from (12) allows for transport and diffusion effects and, furthermore, does not assume instantaneous photochemical response of $\mathrm{HNO}_{3}$. The two ratios are nearly equal, except at high latitudes. Large differences are confined to the troposphere and lower stratosphere; the largest differences are found in the spring hemisphere.

At solstice there are marked differences in $\mathrm{HNO}_{3}$ and in the other odd nitrogen species. For $\mathrm{HNO}_{3}$ (Figure 2) the winter differences are attributed both to separate transport and to failure of the photochemical equilibrium approximation. The high-altitude differences in the winter hemisphere are produced by downward transport of low values of $\mathrm{HNO}_{3}$ in the STM. In the FTM, when photochemical production and loss are both zero, the ratio $\mathrm{HNO}_{3} / \mathrm{NO}_{y}$ is fixed to its last value before polar night. Consequently, during winter the FTM $\mathrm{HNO}_{3}$ values at high-altitudes remain fixed. Between 100 and 10 mbar the $\mathrm{STM} \mathrm{HNO}_{3}$ peak values are transported to lower altitudes during winter. In the FTM, values of $\mathrm{HNO}_{3}$ are very low, reflecting the decrease in $\mathrm{NO}_{2}$ as winter approaches. The solution to the continuity equation neglecting transport is

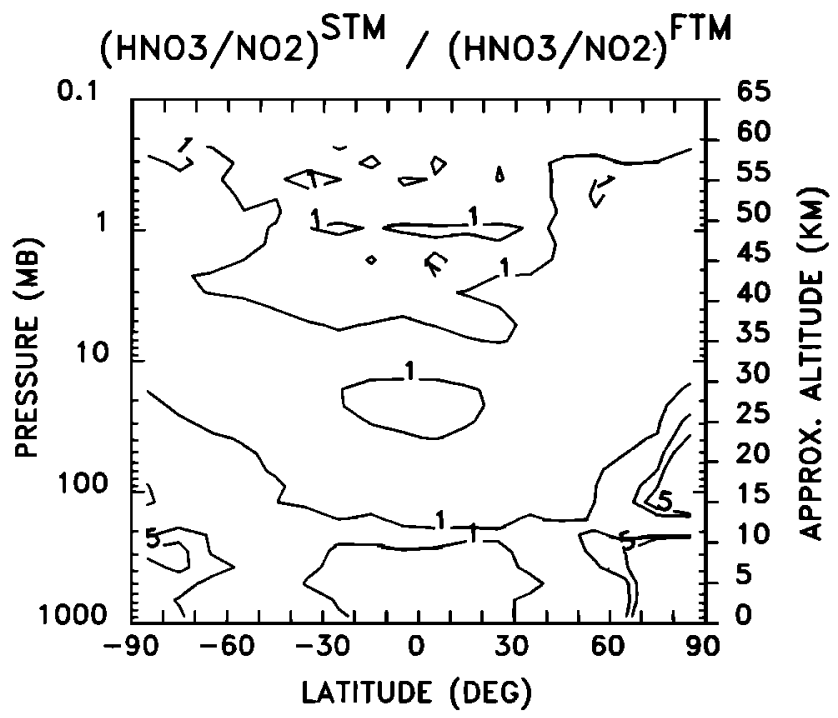

Fig. 1. $\mathrm{HNO}_{3} / \mathrm{NO}_{2}$ from the separate transport model (STM) compares well with the photochemical equilibrium ratio $\mathrm{HNO}_{3} / \mathrm{NO}_{2}$ from the family transport model (FTM). The ratios are nearly equal, except at high latitudes in the troposphere and lower stratosphere, with largest differences in the spring hemisphere.

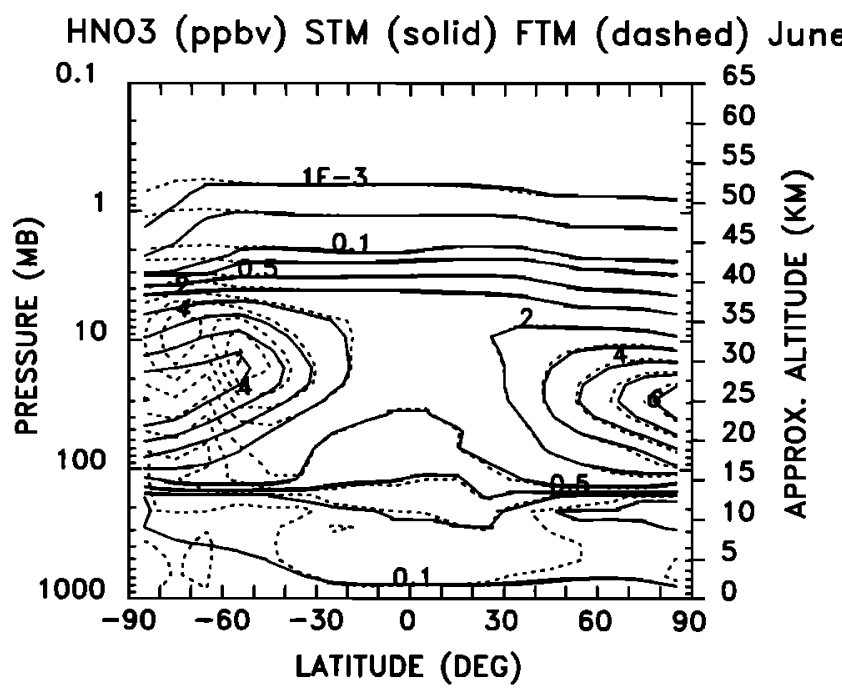

Fig. 2. There are substantial differences at high latitudes in the winter hemisphere for $\mathrm{HNO}_{3}$ transported separately (solid curves) and through family approximations (dashed curves).

$$
\left[\mathrm{HNO}_{3}\right]^{t}=\frac{P}{L}\left(1-e^{-L \Delta t}\right)+\left[\mathrm{HNO}_{3}\right]^{0} e^{-L \Delta t}
$$

where $P=k_{\mathrm{OH}, \mathrm{NO}_{2}, \mathrm{M}}[\mathrm{OH}]\left[\mathrm{NO}_{2}\right]$ and $L=J_{\mathrm{HNO}_{3}}+$ $k_{\mathrm{OH}, \mathrm{HNO}}[\mathrm{OH}]$. The FTM requires that the solution be approximated by its photochemical equilibrium limit, $\left[\mathrm{HNO}_{3}\right]^{t}=P / L$, and does not consider that the photochemical lifetime of $\mathrm{HNO}_{3}$ becomes long (i.e., $e^{-L . \Delta t} \rightarrow 1$ ) and that $\left[\mathrm{HNO}_{3}\right]^{t}$ should be closer to $\left[\mathrm{HNO}_{3}\right]^{0}$ than to $P / L$. Because $\mathrm{HNO}_{3} / \mathrm{NO}_{2}$ takes an unrealistically low value and because $\mathrm{NO}_{y}$ is nearly unaffected by these differences in odd nitrogen species partitioning (Figure 3 ), the values of other odd nitrogen species, especially $\mathrm{N}_{2} \mathrm{O}_{5}$, become large (Figure 4). These differences in odd nitrogen partitioning are significant for half the year, but they disappear as summer approaches. In Figure 5 the difference in $\mathrm{HNO}_{3}$ calculated by the two formulations for a repeating annual cycle is given at $85^{\circ} \mathrm{N}$, as a function of time. The differences become significant about 20 days past the fall equinox and persist until about 10 days past the spring equinox. It may be possible to improve family approximations by accounting for the time lags from (26) instead of assuming instantaneous photochemical equilibrium.

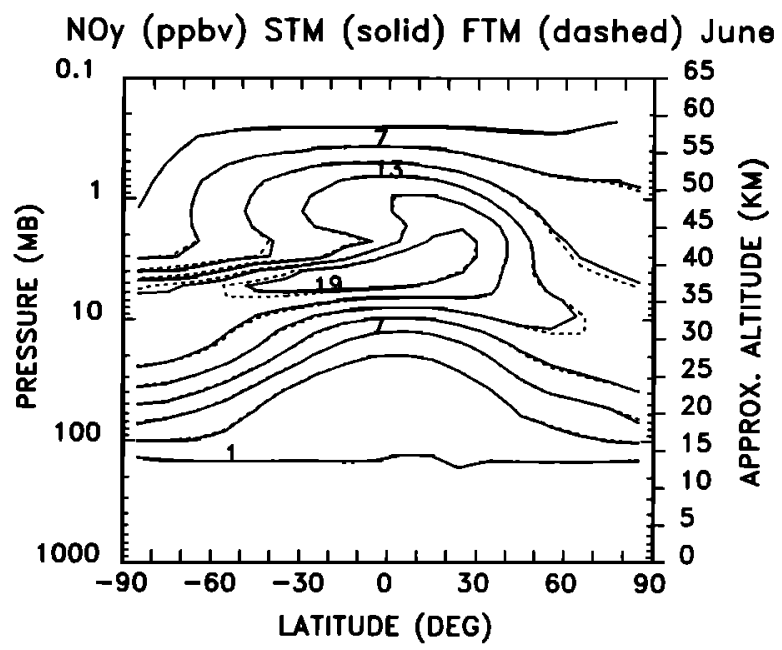

Fig. 3. Total odd nitrogen for the STM (solid curves) compares well with total odd nitrogen for the FTM (dashed curves). 


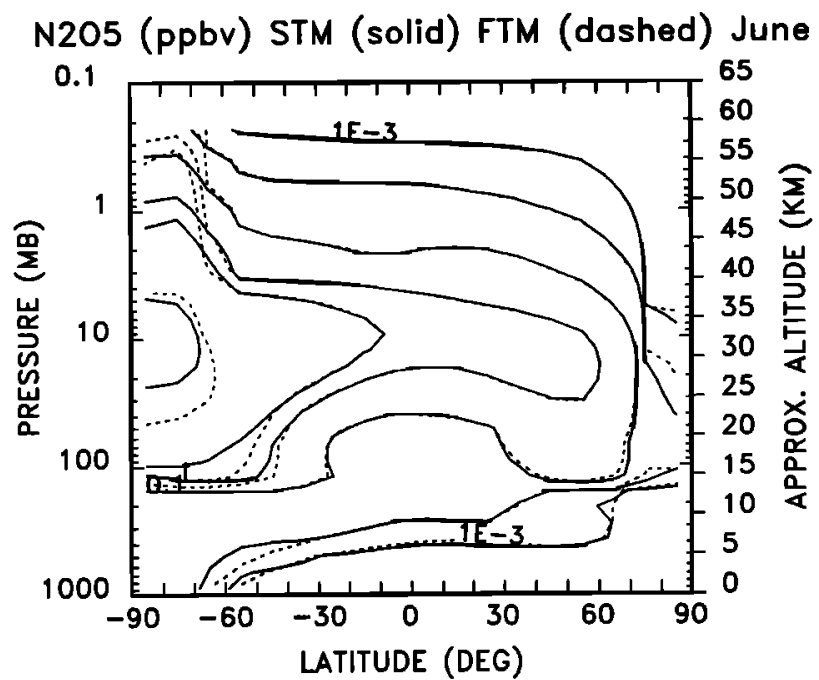

Fig. 4. Solstice $\mathrm{N}_{2} \mathrm{O}_{5}$ from the STM (solid curves) compares well with $\mathrm{N}_{2} \mathrm{O}_{5}$ from the FTM (dashed curves). $\mathrm{N}_{2} \mathrm{O}_{5}$ levels in the FTM are higher than the levels in the STM in the winter hemisphere.

The differences in $\mathrm{NO}_{y}$ calculated by the STM and FTM (Figure 3) are much less than the differences in partitioning among the species. As discussed previously, the agreement of $\mathrm{NO}_{y}$ would imply cancellation of terms, for example, the production of $\mathrm{NO}_{x}$ from $\mathrm{N}_{2} \mathrm{O}_{5}\left(2 \mathrm{~L}\left(\mathrm{~N}_{2} \mathrm{O}_{5}\right)_{\mathrm{NO}_{r}}\left[\mathrm{~N}_{2} \mathrm{O}_{5}\right]^{0}\right)$ with the loss of $\mathrm{N}_{2} \mathrm{O}_{5}\left(2 L\left(\mathrm{~N}_{2} \mathrm{O}_{5}\right)_{\mathrm{NO}_{\mathrm{r}}}\left[\mathrm{N}_{2} \mathrm{O}_{5}\right]^{t}\right)$, and the production of $\mathrm{NO}_{\mathrm{r}}$ from $\mathrm{HNO}_{3}\left(\mathrm{~L}\left(\mathrm{HNO}_{3}\right)_{\mathrm{NO}}\left[\mathrm{HNO}_{3}\right]^{0}\right)$ with the loss of

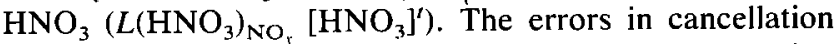
depend on the sign and rate of the species concentration change, for example, the production of $\mathrm{NO}_{x}$ from $\mathrm{N}_{2} \mathrm{O}_{5}$ exceeds the loss of $\mathrm{N}_{2} \mathrm{O}_{5}$ when $\mathrm{N}_{2} \mathrm{O}_{5}$ is decreasing. The small differences observed in $\mathrm{NO}_{y}$ in this experiment suggest the validity of the assumption of slow day-to-day changes in species concentrations for the FTM.

Total $\mathrm{Cl}_{y}=\mathrm{Cl}+\mathrm{ClO}+\mathrm{ClONO}_{2}+\mathrm{HCl}+\mathrm{HOCl}$ is nearly identical in both models. In the STM, as for $\mathrm{HNO}_{3}, \mathrm{ClONO}_{2}$ is transported to the lower stratosphere during the winter (Figure $6 a$ ), and the differences persist at equinox (Figure

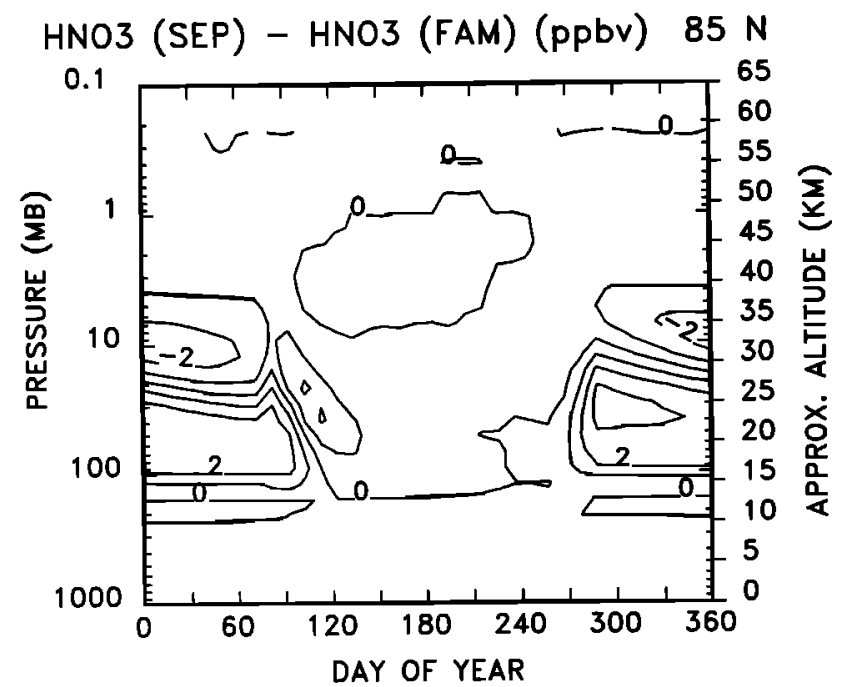

Fig. 5. The difference between $\mathrm{HNO}_{3}$ transported separately and from family approximations for a repeating annual cycle becomes significant at about day 280 (October 10), and after an initial rise it remains nearly constant until about day 90 (April 1).

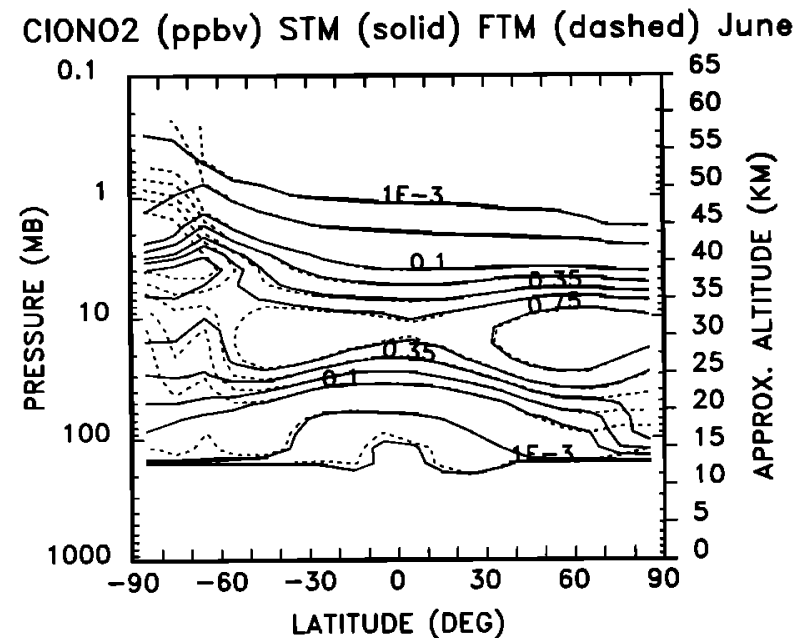

Fig. 6a. $\mathrm{ClONO}_{2}$ differences are pronounced in the winter hemisphere, where large values of $\mathrm{ClONO}_{2}$ are transported downward in the STM but not in the FTM. The lower stratosphere (15-25 $\mathrm{km}$ ) values of $\mathrm{ClONO}_{2}$ are substantially larger in the STM than in the FTM at high latitudes, even at summer solstice.

$6 b)$. The STM maintains slightly higher values of $\mathrm{ClONO}_{2}$ (and slightly lower values of $\mathrm{ClO}$ ) in the lower stratosphere through most of the year. This contrasts with odd nitrogen partitioning; although there are large wintertime differences in the calculated values of $\mathrm{HNO}_{3}$ and $\mathrm{N}_{2} \mathrm{O}_{5}$, these differences are less long-lived.

Although there are substantial high-latitude differences in both odd nitrogen and odd chlorine species, the calculated ozone distributions are remarkably similar. Contours of ozone calculated by the STM and FTM are compared at equinox and solstice in Figure 7. The good agreement is observed because the differences in $\mathrm{NO}_{2}$ and $\mathrm{ClO}$ are confined to the high-latitude lower stratosphere, where photochemical forcing of ozone is minimal.

\section{Perturbed Atmosphere}

The percent difference in the column ozone for a perturbation in which $\mathrm{Cl}_{y}$ increases from 2.5 to 8.2 parts per billion

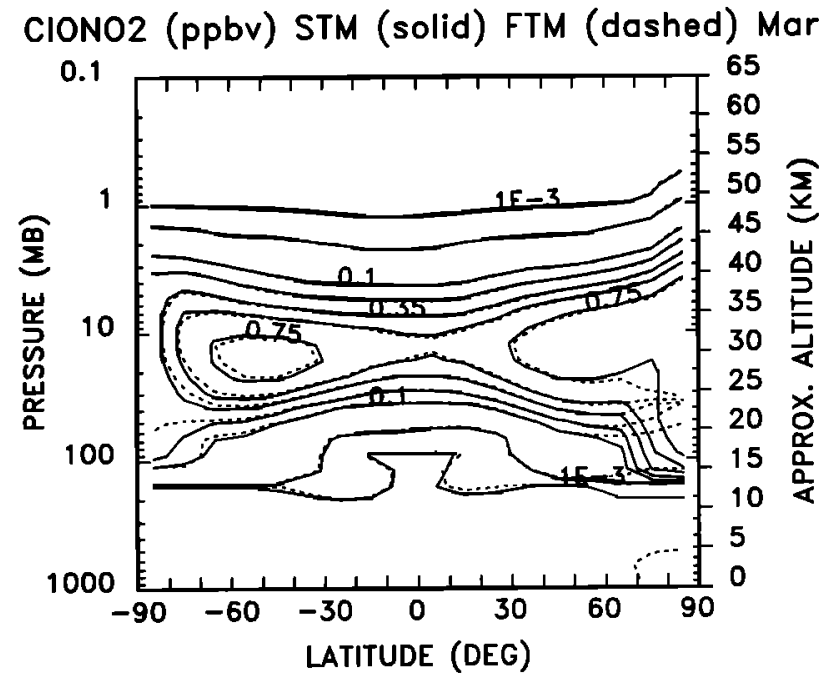

Fig. 6b. $\mathrm{ClONO}_{2}$ values in the lower stratosphere agree at high latitudes by the end of summer (in the fall hemisphere), but they are substantially higher in the STM at high latitudes in the spring hemisphere. 


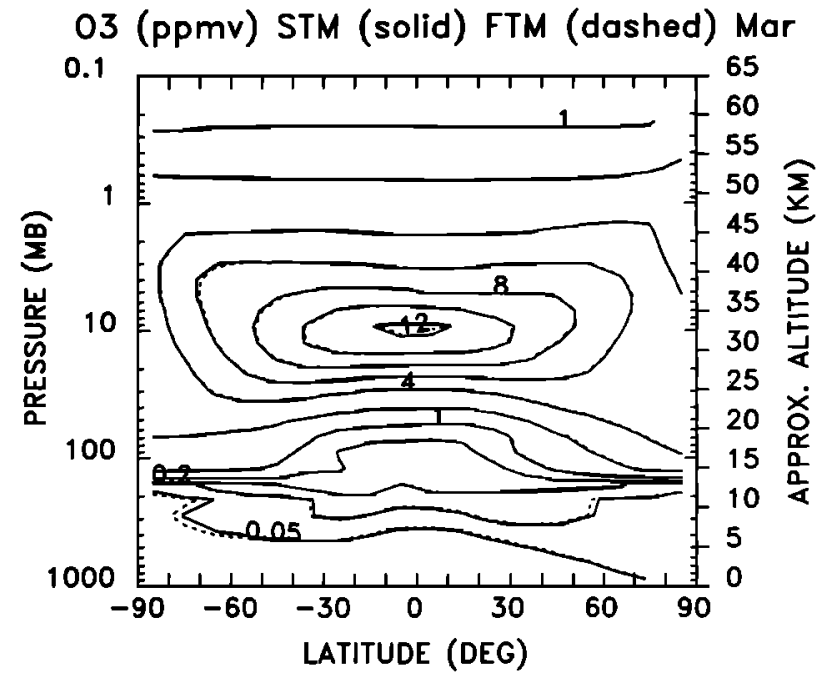

Fig. 7a. Ozone at equinox is nearly identical for the STM and the FTM, in spite of the high-latitude differences in trace species.

by volume (ppbv), $\mathrm{N}_{2} \mathrm{O}$ increases by $20 \%$, and $\mathrm{CH}_{4}$ doubles is given as a function of latitude and season in Figure $8 a$ for the FTM. The ratio of the percent column change for the FTM to the percent column change for the STM is given in Figure $8 b$. The average annual $\mathrm{O}_{3}$ column change is the same $(-2.4 \%)$ for both calculations. The major latitude and temporal structures are also the same; however, the changes from the FTM are somewhat smaller in the southern hemisphere and larger in the northern hemisphere when compared to the STM. The percentage changes in local ozone are given at each altitude and latitude for March and June in Figures $9 a-9 b$. Above $25 \mathrm{~km}$, the FTM and STM produce the same ozone responses, indicating that the small differences in odd nitrogen and chlorine species partitioning here do not have a substantial impact on the calculation. There are larger differences in the lower stratosphere; these are observed because of a consistent difference in $\mathrm{ClONO}_{2}$. A larger proportion of odd chlorine is tied up in $\mathrm{ClONO}_{2}$ in the separate transport case (Figures $6 a-6 b$ ); this is reflected by a smaller concentration of $\mathrm{ClO}$ in the lower stratosphere. The total loss at $\mathbf{2 5} \mathbf{k m}$ is as much as $\mathbf{2 0 \%}$ larger at high latitudes

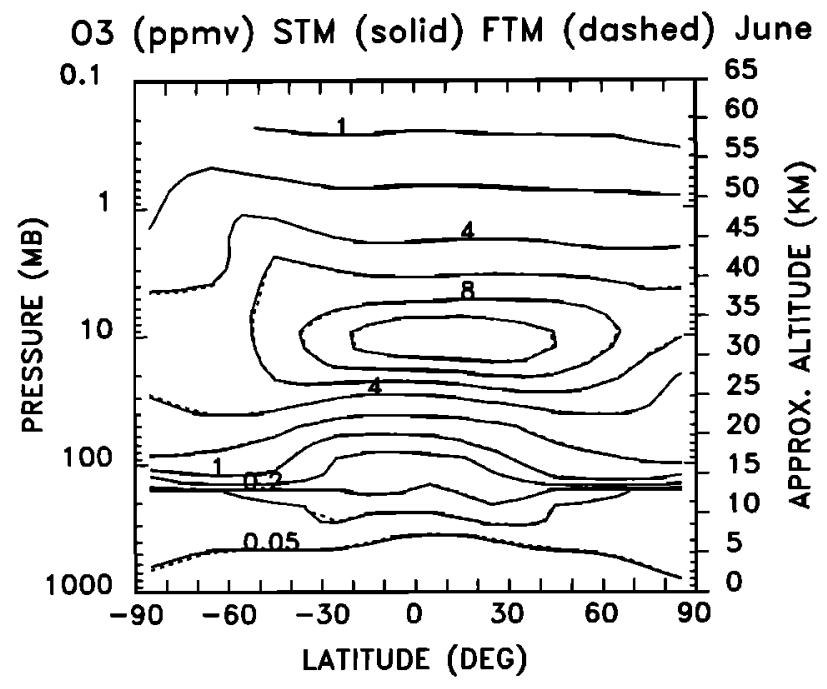

Fig. $7 b$. Same as Figure $7 a$, but for solstice.

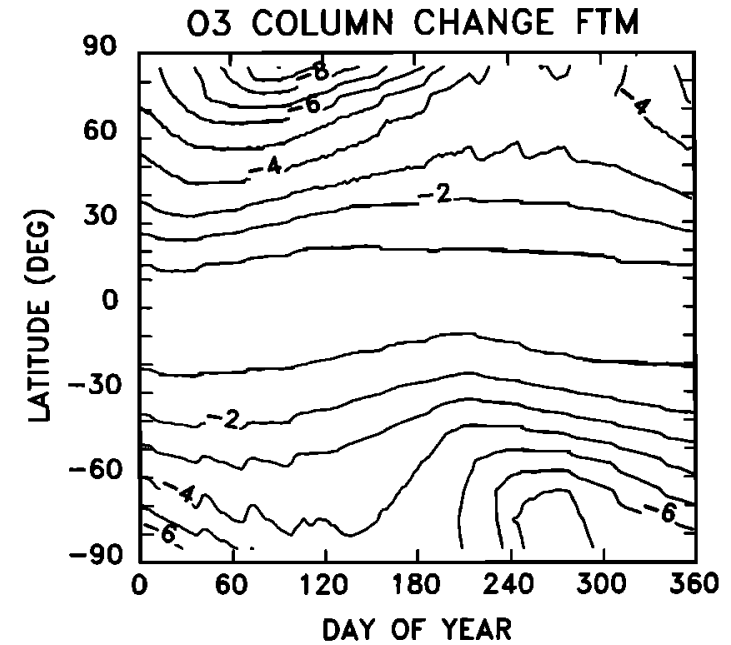

Fig. 8a. The change in column $\mathrm{O}_{3}$ calculated by the FTM in response to a perturbation in which $\mathrm{Cl}_{x}$ increases from 2.5 to 8.2 ppbv, $\mathrm{N}_{2} \mathrm{O}$ increases by $20 \%$, and $\mathrm{CH}_{4}$ is doubled.

for the FTM, because of larger $\mathrm{ClO}$ values. This difference in ozone response is least in the winter hemisphere, as seen by comparing southern and northern high latitudes in Figure $9 b$. In spite of the difference in the lower stratosphere, the major features of the latitude, altitude, and seasonal behavior of the ozone response produced by the STM are reproduced by the FTM. This pattern of ozone response, with the largest ozone depletions at high latitudes, is produced by other models and has previously been discussed [WMO, 1986].

\section{Discussion AND Conclusions}

A fast two-dimensional model has been used to compare calculations of ambient and perturbed atmospheres in which odd nitrogen species are transported as a family, with calculations in which $\mathrm{HNO}_{3}, \mathrm{~N}_{2} \mathrm{O}_{5}, \mathrm{ClONO}_{2}$, and $\mathrm{HO}_{2} \mathrm{NO}_{2}$ are transported separately. There are differences in species partitioning, particularly in the high-latitude lower strato-

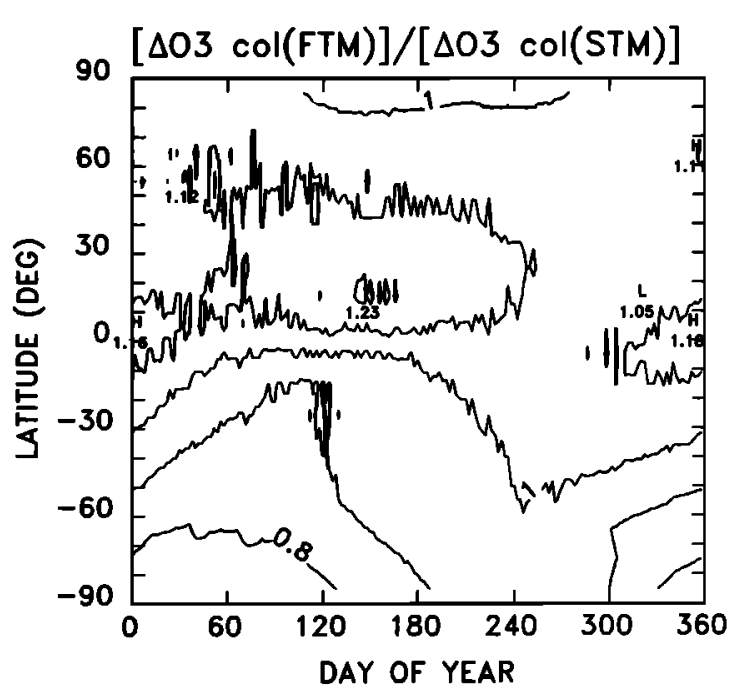

Fig. $8 b$. The ratio of the change in column $\mathrm{O}_{3}$ calculated by the FTM to that calculated by the STM is less than 1 at high southern latitudes and greater than 1 at middle northern latitudes. The major temporal and spatial characteristics of the total ozone changes are the same. 


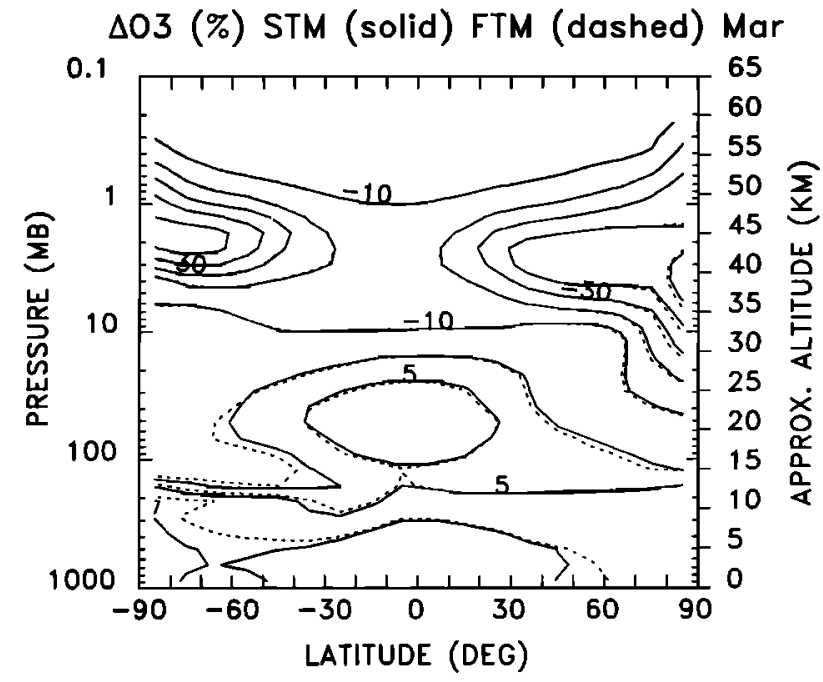

Fig. $9 a$. The percent change in local $\mathrm{O}_{3}$ calculated by the STM (solid curves) compares well with the change calculated by the FTM (dashed curves) at equinox. There are some differences in the calculated response at $30 \mathrm{~km}$ and below, especially in the spring hemisphere.

sphere during winter. The ozone distributions computed for a present-day atmosphere are nearly identical. For increased levels of $\mathrm{Cl}_{y}$ the differences in the ozone distributions are somewhat larger, and there are some differences in the latitudinal distributions of ozone changes calculated by the two models. Although the difference in the percent change in total ozone is as large as $1-2 \%$ at southern high latitudes, it should be noted that the accuracy of this type of model is limited. For example, calculations are uncertain because of uncertainties in photochemical input data, including reaction rate constant data, photodissociation cross sections, and solar flux values, as discussed for a one-dimensional model by Stolarshi and Dollglass [1986]. The accuracy of the calculations is also limited by the photochemical behavior of the troposphere, especially through the source gases $\mathrm{CH}_{4}$, $\mathrm{CH}_{3} \mathrm{Cl}$, and $\mathrm{CH}_{3} \mathrm{CCl}_{3}$, whose stratospheric levels depend on

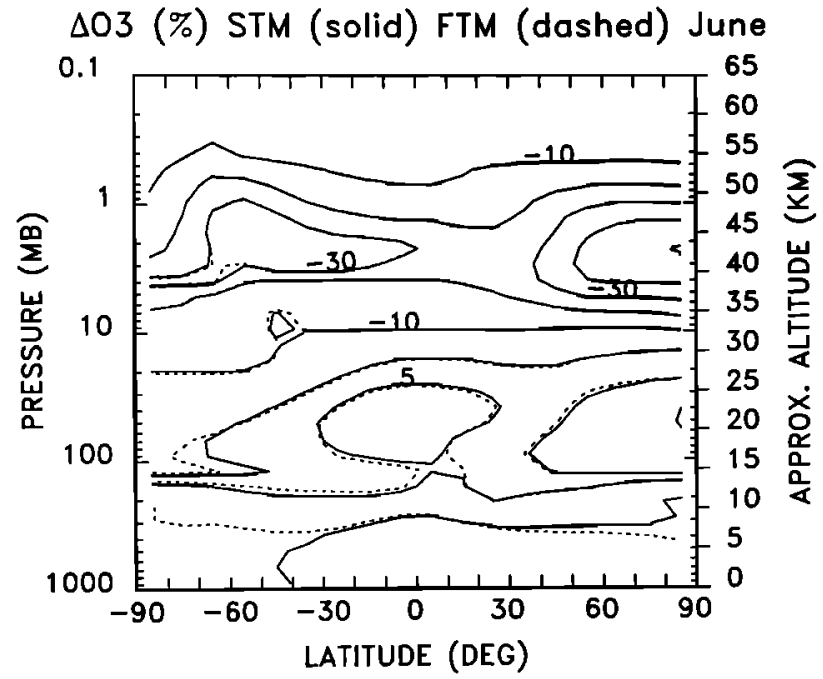

Fig. 9b. The percent change in local $\mathrm{O}_{3}$ calculated by the STM (solid curves) compares well with the change calculated by the STM (dashed curves) at solstice. There are some differences in the calculated response at $25 \mathrm{~km}$ and below in the summer hemisphere. tropospheric $\mathrm{OH}$. The model total ozone is sensitive to the circulation in the lower stratosphere and upper troposphere; the ozone distribution and the distribution of ozone changes are sensitive to the diffusion coefficients [Jackman et al., this issue]. The residual circulation and $K_{y y}$ used in this model are calculated to be consistent with each other and produce distributions of total $\mathrm{O}_{3}, \mathrm{~N}_{2} \mathrm{O}$, and $\mathrm{CH}_{4}$ that are in good agreement with available data for the current atmosphere. These may change not only through feedback processes (heating rate changes produced by ozone changes), but also as a result of changes in the tropospheric forcing. The differences in response of the STM and FTM for a standard perturbation of chlorine, nitrous oxide, and methane is within the accuracy range implied by these sensitivities. For assessment calculations, particularly studies of many multiyear scenarios that place large demands on computer resources, and for studies concerning sensitivity to dynamical assumptions and inputs, to photochemical input data, and to tropospheric trace gas behavior, family approximations are adequate. For detailed comparisons of odd nitrogen species with data, separate transport of species such as $\mathrm{HNO}_{3}$, $\mathrm{N}_{2} \mathrm{O}_{5}$, and $\mathrm{ClONO}_{2}$ is necessary. Because both column and profile measurements of $\mathrm{HNO}_{3}$ are available throughout the year and because there are substantial differences in the values of $\mathrm{HNO}_{3}$ produced by the FTM and STM (Figure 3), subsequent investigations of the atmosphere using this model will include $\mathrm{HNO}_{3}$ as a separately transported species.

There is agreement between $\mathrm{NO}_{y}$ distributions for the FTM and STM, indicating no differences in the net production and loss of $\mathrm{NO}_{v}$. This supports the model assumption of the FTM that photochemical forcing terms can be approximated, using previous time step species concentrations.

Acknowledgments. The authors would like to thank Paul D. Guthrie (NASA Goddard Space Flight Center) for helpful discussions during development of this model and Richard B. Rood and Jack A. Kaye (NASA Goddard Space Flight Center) for useful suggestions to improve the manuscript. We also appreciate the constructive comments of the referees.

\section{REFERENCES}

Allen, M., and J. E. Frederick, Effective photodissociation cross sections for molecular oxygen and nitric oxide in the SchumannRunge bands, J. Atmos. Sci., 39, 2066-2075, 1982.

Cicerone, R. J., S. Walters, and S. C. Liu, Nonlinear response of stratospheric ozone to chlorine injections, J. Geophys. Res., 88, $3647-3661,1983$.

Crutzen, P. J., Ozone production rates in the oxygen-hydrogennitrogen oxide atmosphere, J. Geophys. Res., 76, 7311-7327, 1971 .

DeMore, W. B., J. J. Margitan, M. J. Molina, R. T. Watson, D. M. Golden, R. F. Hampson, M. J. Kurylo, C. J. Howard, and A. R. Ravishankara, Chemical kinetics and photochemical data for use in stratospheric modeling, $J P L P u b l ., 87-4 I, 1987$.

Dopplick, T. G., The heat budget, in The General Circulation of the Tropical Atmosphere and Interactions With Extratropical Latttudes, vol. 2, edited by R. E. Newell, J. W. Kidson, D. G. Vincent, and C. J. Boer, pp. 27-94, MIT Press, Cambridge, Mass., 1974.

Dopplick, T. G., Radiative heating of the global atmosphere: Corrigendum, J. Atmos. Sci., 36, 1812-1817, 1979.

Dunkerton, T., On the mean meridional mass motions of the stratosphere and mesosphere, J. Atmos. Sci., 35, 2325-2333, 1978.

Guthrie, P. D., C. H. Jackman, J. R. Herman, and C. J. McQuillan, A diabatic circulation experiment in a two-dimensional photochemical model, J. Geophys. Res., 89, 9589-9602, 1984. 
Herman, J. R., The response of stratospheric constituents for a solar eclipse, sunrise, and sunset, J. Geophys. Res., 84, 3701-3710, 1979.

Jackman, C. H., P. D. Guthrie, and J. A. Kaye, An intercomparison of nitrogen-containing species in Nimbus 7 LIMS and SAMS data, J. Geophys. Res., 92, 995-1008, 1987.

Jackman, C. H., P. A. Newman, P. D. Guthrie, and M. R. Schoeberl, Effect of computed horizontal diffusion coefficients on two-dimensional $\mathrm{N}_{2} \mathrm{O}$ model distributions, J. Geophys. Res., 93, 5213-5220, 1988 .

Jackman, C. H., A. R. Douglass, P. D. Guthrie, and R. S. Stolarski, The sensitivity of total ozone and ozone perturbation scenarios in a two-dimensional model due to dynamical inputs, J. Geophys. Res., this issue.

Ko, M. K. W., K. K. Tung, D. K. Weisenstein, and N. D. Sze, A zonal mean model of stratospheric tracer transport in isentropic coordinates; Numerical simulations for nitrous oxide and nitric acid, J. Geophys. Res., 90, 2313-2329, 1985.

Ko, M. K. W., M. B. McElroy, D. K. Weisenstein, N. D. Sze, Lightning: A possible source of stratospheric odd nitrogen, $J$. Geophys. Res., 91, 5395-5404, 1986.

McCartney, E. J., Optics of the Atmosphere, John Wiley, New York, 1976.

McRae, G. J., W. R. Goodin, and J. H. Seinfeld, Numerical solution of the atmospheric diffusion equation for chemically reacting flows, J. Comput. Phys., 45, 1-42, 1982.

Newell, R. E., W. K. Oson, D. G. Vincent, and G. J. Boer, The General Circulation of the Tropical Atmosphere and Interactions With Extratropical Latitudes, vol. 1, MIT Press, Cambridge, Mass., 1972.

Newman, P. A., M. R. Schoeberl, and R. A. Plumb, Horizontal mixing coefficients for two-dimensional chemical models calculated from National Meteorological Center data, J. Geophys. Res., 91, 7919-7924, 1986.

Newman, P. A., M. R. Schoeberl, R. A. Plumb, and J. E. Rosenfield, Mixing rates calculated from potential vorticity, J. Geophys. Res., 93, 5221-5240, 1988.

Nicolet, M., Nitrogen oxides in the chemosphere, J. Geophys. Res., $70,679-689,1965$.
Plass, G. N., G. W. Kattawar, and F. E. Catchings, Matrix operator theory of radiative transfer, 1, Rayleigh scattering, Appl. Opt., 12, 314-329, 1973.

Prather, M. J., Numerical advection by conservation of secondorder moments, J. Geophys. Res., 91, 6671-6681, 1986.

Pyle, J. A., and C. F. Rogers, Stratospheric transport by stationary planetary waves-The importance of chemical processes, $Q . J . R$. Meteorol Soc., 106, 421-446, 1980.

Rosenfield, J. E., M. R. Schoeberl, and M. A. Geller, A computation of the stratospheric diabatic residual circulation using an accurate radiative transfer model, J. Atmos. Sci., 44, 859-876, 1987.

Solomon, S., One- and two-dimensional photochemical modeling of the chemical interactions in the middle atmosphere $(0-120 \mathrm{~km})$, NCAR Coop. thesis, NCAR/CT-62, Univ. of Calif. and Natl. Cent. for Atmos. Res., Boulder, Colo., 1981.

Solomon, S., R. R. Garcia, and F. Stordal, Transport processes and ozone perturbations, J. Geophys. Res., 90, 12,981-12,989, 1985.

Stolarski, R. S., and A. R. Douglass, Sensitivity of an atmospheric photochemistry model to chlorine perturbations including consideration of uncertainty propagation, J. Geophys. Res., 91, 7853$7864,1986$.

Turco, R. P., and R. C. Whitten, A note on the diurnal averaging of aeronomical models, J. Atmos. Terr. Phys., 40, 13-20, 1978.

World Meteorological Organization, The stratosphere 1981; Theory and measurements, Rep. I1, Global Ozone Res. and Monit. Proj., Geneva, 1981.

World Meteorological Organization, Atmospherıc ozone 1985, Rep. 16, Global Ozone Res. and Monit. Proj., Geneva, 1986.

A. R. Douglass, C. H. Jackman, and R. S. Stolarski, Atmospheric Chemistry and Dynamics Branch, Code 616, NASA Goddard Space Flight Center, Greenbelt, MD 20771.

(Received August 2, 1988; revised March 24, 1989; accepted March 24, 1989.) 